\title{
Makué (Aore Island, Santo, Vanuatu): A new Lapita site in the ambit of New Britain obsidian distribution
}

\author{
Jean-Christophe Galipaud ${ }^{1}$ and Mary Clare Swete Kelly²
}

\author{
${ }^{1}$ Research Institute for Development (IRD), \\ P0 Box A5 98848 Nouméa, \\ New Caledonia. \\ galipaud@noumea.ird.nc \\ ${ }^{2}$ Archaeology and Natural History, \\ Research School of Pacific and Asian Studies, \\ Australian National University, \\ Canberra, ACT 0200, Australia. \\ maryclare.swetekelly@anu.edu.au
}

\section{Obsidian and Lapita}

The emergence of Lapita in the New Britain area is closely associated with the use of flaked obsidian artefacts. Sources of raw material include, among others, the Willaumez Peninsula in New Britain and later the Lou and Pam Islands, both of which are situated in the Bismarck Archipelago (Ambrose 1976). Obsidian is particularly important for the interpretation of long-distance movement of artefacts because it is possible to determine its source with a high level of accuracy. Obsidian from both of the aforementioned sources found in Lapita sites has also been used to infer the chronology of occupation as well as the patterns of movement and exchange (Green 1987; Specht 2002; Summerhayes 2003).

Obsidian is relatively rare in most Lapita sites in Remote Oceania which can be attributed to the lack of suitable sources of volcanic glass beyond the Bismarck archipelago. In a few sites from Fiji, New Caledonia and north Vanuatu a limited amount of small obsidian flakes sourced to the Bismarck have been considered to attest to long distance exchange systems in the Lapita sphere. However, up until now, relatively large amounts of obsidian from sites in Remote Oceania have only been identified in the Reef Islands, particularly Nenumbo (Green 1976, 1979; Sheppard 1993; Sheppard and Green 1991).

Herein the discovery and source data concerning obsidian artefacts found on the recently discovered site of Makué on Aore Island (south Santo, Vanuatu) are presented. The large amount of obsidian flakes found there, the early dates from the site as well as the pottery style suggest that Makue represents an early, if not founding, Lapita settlement in Vanuatu. A comprehensive description of the site will be published shortly. 


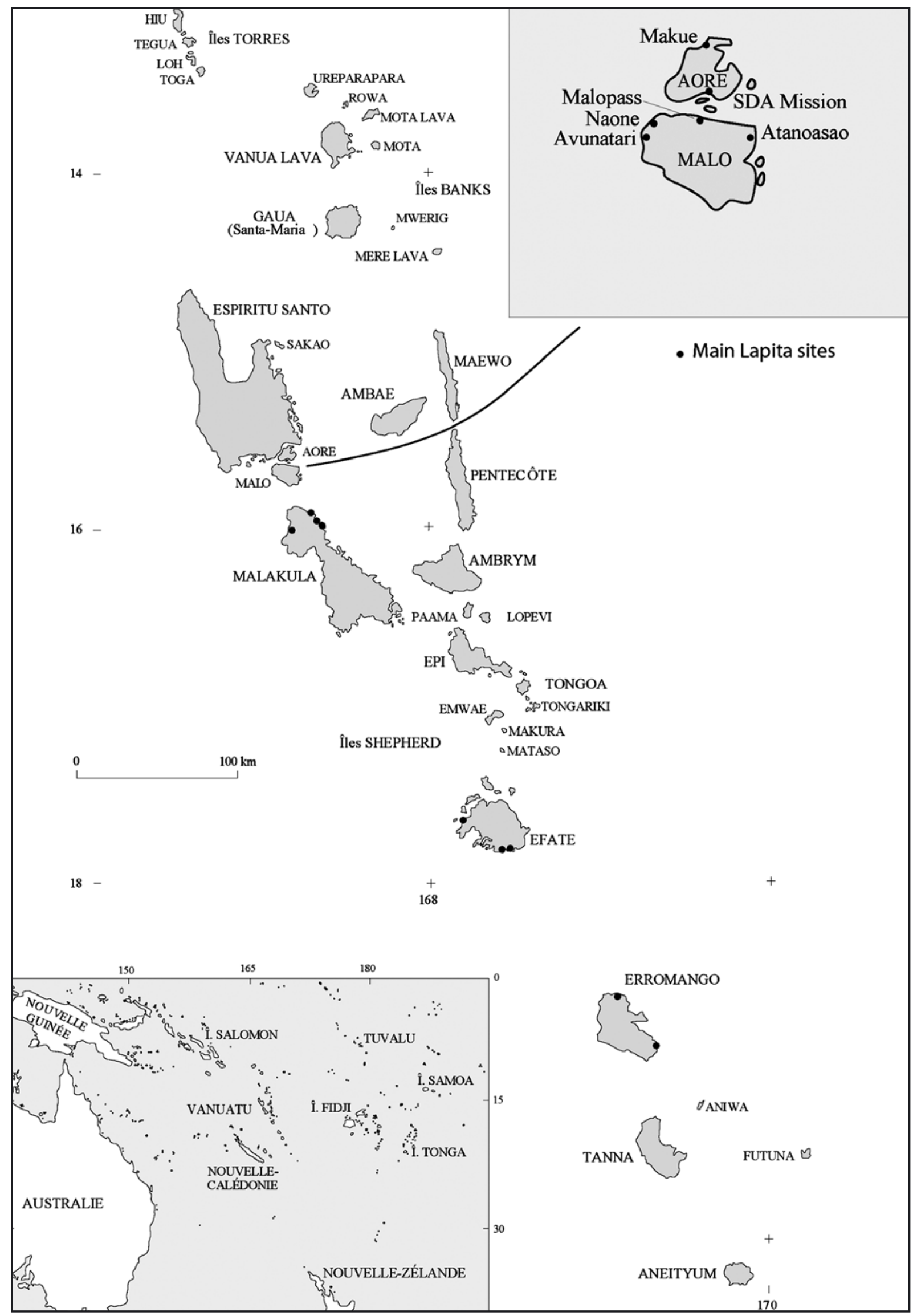

Figure 1. A map of Vanuatu indicating the positions of the main Lapita sites currently identified. 


\section{Lapita in Vanuatu}

Until relatively recently few Lapita sites had been identified in Vanuatu (Figure 1). Apart from several very disturbed Lapita sites on Malo Island in the north (Hedrick 1971), the only other sites that had been located prior to the year 1997 were the site of Erueti on the central island of Efate (Garanger 1972; Hébert 1965), Ifo on Erromango in the south (Bedford 2006; Spriggs and Wickler 1989) and Malakula (Malua Bay) in the north (Bedford 2006). Limited excavations were undertaken at Erueti where the site proved to be very disturbed (Garanger 1972). While the site of Ifo was less disturbed the some $1.5 \mathrm{~m}$ of cultural stratigraphy in places, covering a 1000 year period, restricted the potential of large area excavations. At both sites the sum total of dentate-stamped Lapita sherds was small. A single dentate-stamped sherd only was recovered from the predominantly plainware site of Malua Bay (Bedford 2006). The paucity of Lapita sites in the Vanuatu islands could hardly, however, be explained by a lack of interest in these islands during the initial period of exploration and settlement, rather the invisibility of these early sites is due largely to the tectonically and volcanically active nature of the archipelago (Bedford 2003, 2006; Pineda and Galipaud 1998).

From 1997 onwards, intensive research in the Santo area (Galipaud 2000) led to the discovery of many Lapita sites, some in a good state of preservation. These sites are generally covered by a metre or more of sandy humic soil and located on uplifted terraces behind the present shore. They were discovered after a thorough study of environmental changes and uplift history in the region (Pineda and Galipaud 1998). Lapita sites were also identified on the islands of north-east Malekula in 2001 and 2002 (Bedford 2003) and in 2003, a well preserved Lapita site with a cemetery was fortuitously found on Efate (Bedford et al 2006). More sites are likely to be discovered in similar environments in the future.

Among the many sites found in the Santo-Malo area, Makué, in the northern part of Aore, is outstanding for its general preservation, its early dates and evidence of at least two subsequent short Lapita occupations with large amounts of obsidian flakes, among other cultural remains. A short description of the site and its excavation history follows.

\section{The Makué Lapita site}

A survey in 2000 on Aore Island was focused on areas where ancient beach deposits could be located. The two areas chosen for survey were the north point around the Aore Beach Resort and the south-western coast near the Seven-Day Adventists' mission (Figures 1 and 2).

In the north of Aore, decorated Lapita sherds were found in several instances just below the surface, demonstrating that this area had been settled some 3000 years ago. The patterns

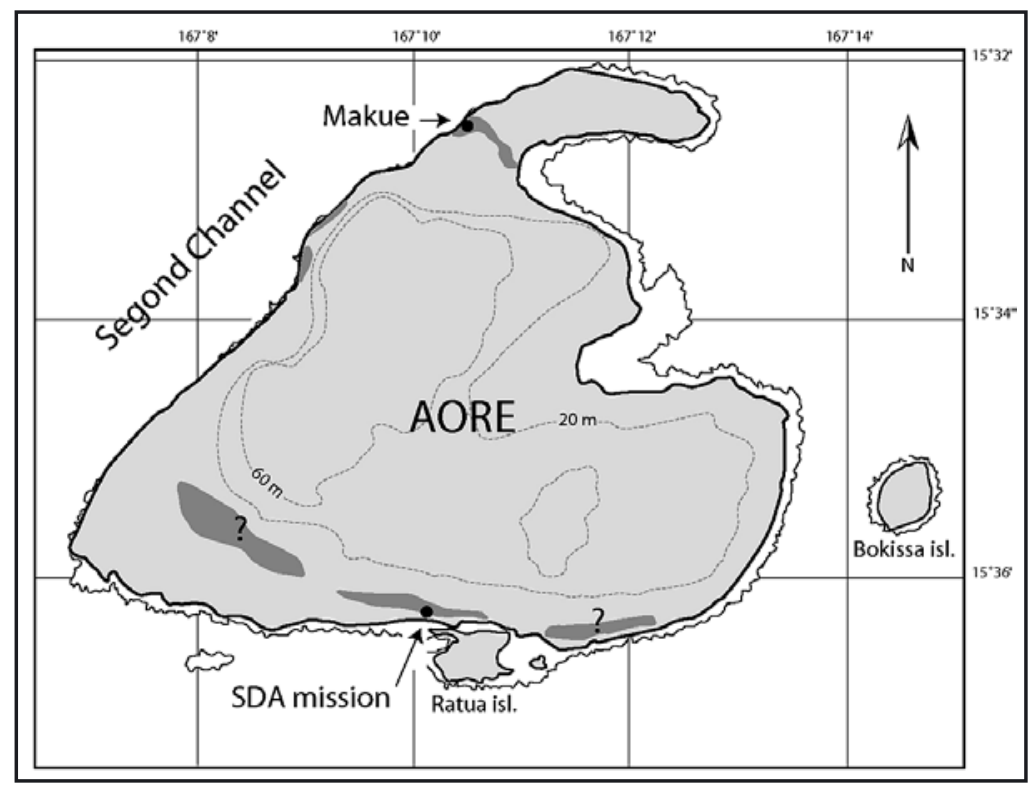

Figure 2. A map of Aore Island indicating the main Lapita sites (in dark grey) and potential Lapita sites (dark grey with question mark). 
of deposition suggest that remains from this early period are scattered along several hundred metres on the north-west coastline around the Aore Resort, and might extend as much as 100 meters to the east along what used to be the north point of Aore.

Along the west coast, several surface scatters with decorated Lapita were also located near Baracira but have not yet been excavated. Another Lapita occupation was located at Port Latour, in the south of Aore. This site, opposite the Batuni Urunga Lapita site on Malo Island (also known as Malo Pass) (Hedrick 1971) was tested in 2003. Two other potential Lapita occupations on the south-west and south-east coast await further investigation.

Like Malo, most sites on Aore Island are in a poor state of preservation, reflecting their proximity to the sea and their shallow nature. Most sites are now largely destroyed and scattered sherds are the only indicators of early human activity. In contrast, the Makue site is exceptionally well preserved and the excavations so far have given valuable insights into the early Lapita occupation in the area.

\section{Excavation History}

The Makué site (or Aore Resort Lapita site, as it was called in 2002) is located on the north western coast of Aore, facing the South Santo coast. It is separated from the island of Santo by the narrow Segond Channel (Figure 2). The north coast of Aore is formed by an elongated sand strip, stabilised by dense secondary vegetation. Several low terraces ( 1 to 3 metres high) attest to the uplift of ancient shorelines. The site is in a coconut plantation, six to eight meters above current sea-level, on the upper terrace and close by the Aore Resort.

In contrast to the many Lapita sites found on Malo Island in a similar environment, the archaeological deposits here are extensive and do not seem to have been greatly affected by either their initial proximity to the sea, or the subsequent uplift processes. Parts of the site, however, were probably disturbed by the construction of an American base camp during the Second World War.

The Makué site was discovered in 2001 through extensive drilling work, in the north Aore area. In 2002, a series of test pits behind the Aore Resort (Area A, see Figure 3) uncovered a substantial quantity of remains, but revealed no structures. Only a possible pit, containing some human bones, was found just beneath the surface. It cannot yet be confidently associated with the Lapita occupation. Among the other remains recovered in 2002 was a relatively large number of obsidian flakes.

In 2003 , a $12 \mathrm{~m}^{2}$ area was excavated beside the Aore Resort, close to the sea (Area B). An in situ Lapita layer was identified, containing several fireplaces, large pottery sherds (including the pedestal of an open bowl), shell artifacts, faunal remains as well as some additional obsidian flakes. In November 2005, the Area B excavation was extended and this provided further

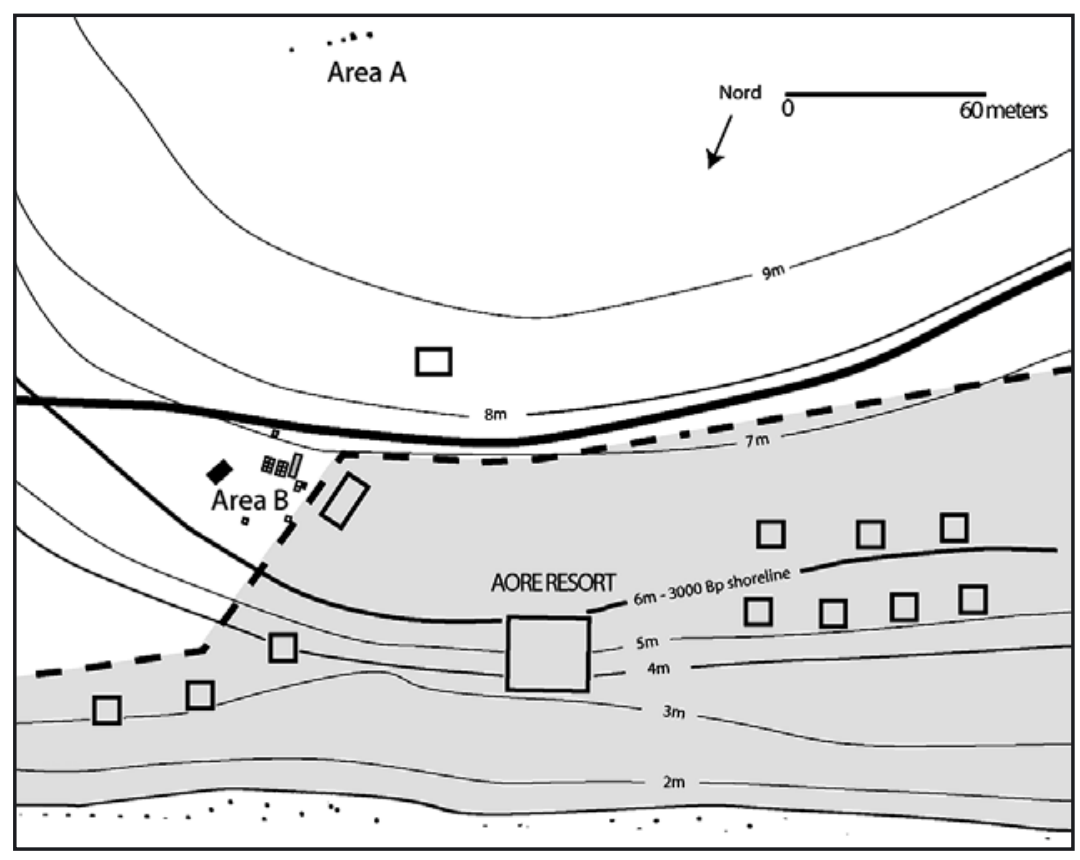

Figure 3. Location of excavated area on the northern coast of Aore Island. 
clarification of the stratigraphy at the site. This excavation also recovered another in situ archaeological deposit below the first one containing large fragments of pottery vessels.

\section{Stratigraphy}

The stratigraphy in Area A differs slightly from that in Area B. In Area A (Figure 4), a dark, humic, sandy layer varying between 15 and 40 centimetres in depth (1) overlays a fine, sandy, grey sediment (2). An indurated layer (3) appears in all test pits between 60 and 80 centimetres. The irregularity of the thickness of the first layer suggests some recent surface disturbance, possibly during the Second World War. Remains of glass bottles, as well as other modern artefacts, attest to some disturbance. Lapita sherds found in Area A are small and fragmented. They occur mostly in the lower layers but are also present in the top-most, disturbed layer. Some features have been observed in the sections and at the bottom of some of the trenches. The most obvious is the base of a small pit filled with humic sediment and containing fragments of one or several human skeletons.

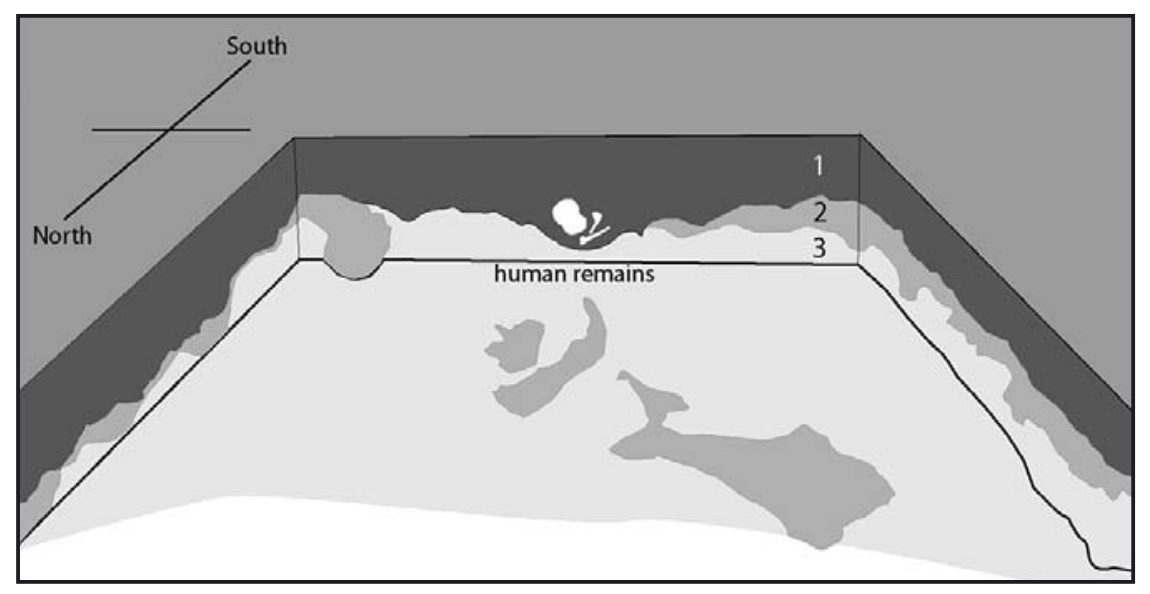

Figure 4. Profile diagram, Area A, Makué 2002.

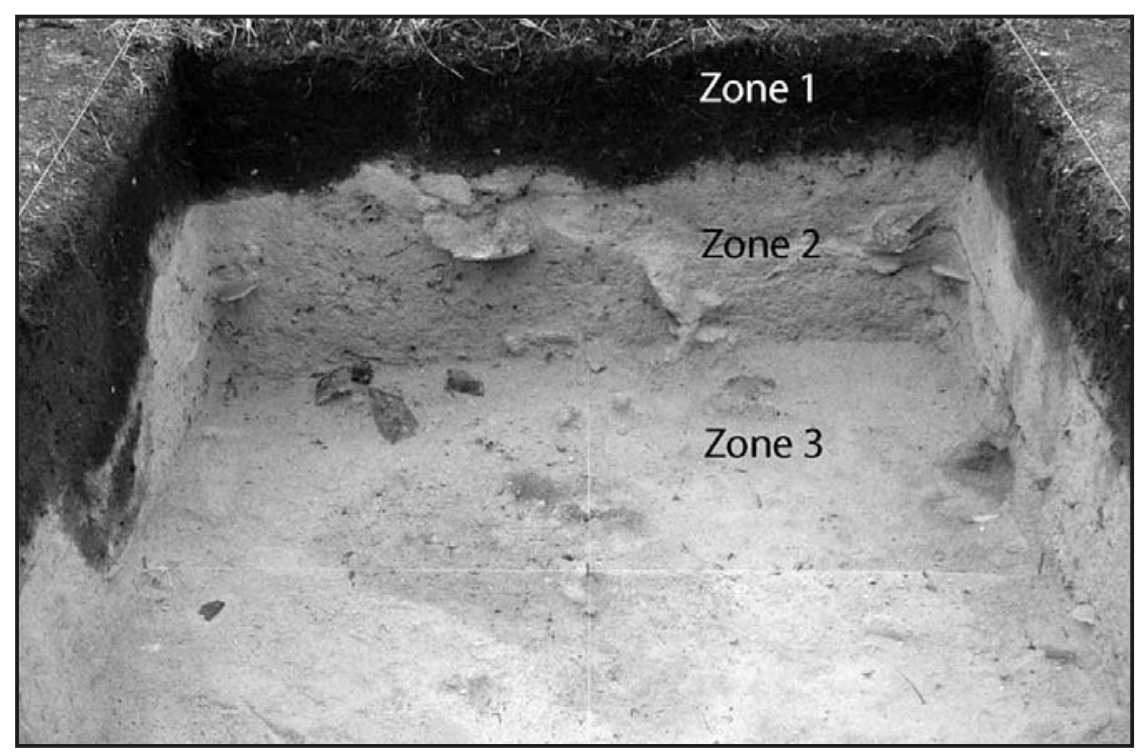

Figure 5. Photo of Area B profile, Makué 2005. 
The stratigraphy of Area B is similar to that in Area A but the cultural levels are deeper and better preserved (Figure 5). The top $50 \mathrm{~cm}$ is a dark, humic, sandy sediment becoming lighter with depth (Zone 1). This contains shells and fragmented pottery. Below is a grey, ashy compacted layer with evidence of burning, and accumulation of large pieces of in situ cultural material, especially turtle bone (Zone 2). A sterile fine, sandy layer separates this level from a deeper fine, sandy deposit containing cultural remains (Zone 3). This contains fewer bones but more common large fragments of pottery. Culturally sterile sand, mixed with coral cobbles, lies below this layer.

The overall stratigraphy suggests that the Lapita occupations occurred very close to the shore in a sandy environment without vegetation. Later disturbances by the sea is evident in some parts of the excavated area but the general condition of the site is excellent with few disturbances having been observed in Zones 2 and 3, which appear to be in situ.

\section{Dating Makué}

Absolute dating of Vanuatu sites is often difficult due to the lack of good quality dating material. Makué, however, has in some instances delivered good amounts of charcoal especially in the lower levels. Dating of shell has not been favoured because the Delta $R$ value for marine shells in the region has not been precisely established. Relative dating was also possible with some level of confidence due to the fact that a large amount of obsidian flakes sourced to the Bismarck Archipelago had been recovered (see below). The only other sites in Remote Oceania with similar quantities of obsidian from the Bismarck Archipelago are sites in the Reef and Santa-Cruz Islands, which have been tentatively dated to around 3200-2900 BP (Green 1991). A similar antiquity was expected for Makué.

Three AMS dates were obtained for this site in 2003 and four more in 2005. The first one [WK-11447] is from the bottom cultural layer in the 2002 B1 test pit (close by the 2003 Area B excavation), the other two come respectively from a fireplace [WK-13722] on the in situ cultural level (Zone 2) and from below this same level [WK-13721] in the Area B 2003 excavation. In 2005, the two cultural levels were dated again in Area B [Wk-19704] [Wk-19705] as well as in a test pit closer to the sea (F16) where the stratigraphy was not so obvious but nevertheless produced evidence of several occupations partly disturbed by the sea [Wk-19706] [Wk-19707]. Results of the dating are presented in the table below:

Table 1. Radiocarbon dates obtained from the Makué site. Calibration was performed using 0xCal v4.4 Bronk Ramsey (2007) and SHCal04 Southern Hemisphere calibration (McCormac et al. 2004).

\begin{tabular}{|c|c|c|c|c|}
\hline 14C Lab.C ode & CRA & Cal $1 \sigma(68.2 \%$ probability $)$ & Cal $2 \sigma(95.4 \%$ probability) & Context \\
\hline Wk-19704 & $2891 \pm 32 B P$ & $3070 \mathrm{BP}(68.2 \%) 2966 \mathrm{BP}$ & $3158 \mathrm{BP}(95.4 \%)$ 2925BP & 2005 / Area B, Zone 2 \\
\hline Wk-19705 & $2962 \pm 32 B P$ & 3207BP $(59.4 \%)$ 3078BP & $3245 B P(95.4 \%) 3004 B P$ & 2005 / Area B, Zone 3 \\
\hline Wk-19706 & $2800 \pm 34 \mathrm{BP}$ & $2947 \mathrm{BP}(68.2 \%) 2863 \mathrm{BP}$ & 2992BP (95.4 \%) 2795BP & 2005 / Area B, F16 layer 2-9 \\
\hline Wk-19707 & $2886 \pm 32 B P$ & $3065 B P(68.2 \%) 2965 B P$ & $3156 \mathrm{BP}(95.4 \%) 2890 \mathrm{BP}$ & 2005 / Area B, F16, layer 2-13 \\
\hline Wk-13721 & $2957 \pm 51 B P$ & $3215 \mathrm{BP}(68.2 \%) 3007 \mathrm{BP}$ & $3320 \mathrm{BP}(95.4 \%) \quad 2964 \mathrm{BP}$ & 2003 / Area B, Zone 3 \\
\hline Wk-13722 & $2982 \pm 50 B P$ & $3245 \mathrm{BP}(68.2 \%) 3078 \mathrm{BP}$ & $3334 \mathrm{BP}(95.4 \%) 3000 \mathrm{BP}$ & 2003 / Area B, Zone 2 \\
\hline Wk-11447 & $2935 \pm 41 B P$ & $3161 \mathrm{BP}(68.2 \%) 3005 \mathrm{BP}$ & $3238 \mathrm{BP}(95.4 \%) 2959 \mathrm{BP}$ & 2002 / Area B, B1, layer 10-2 \\
\hline
\end{tabular}

In Area A in 2002, little charcoal was found and the area could not be dated. All samples from Area $B$ are in secure stratigraphic units and in clear association with other cultural remains. Unfortunately, the small 
size of the samples did not allow for a prior determination of the wood species, and therefore the discussion of the results is limited due to the potential problem of in-built age in unidentified charcoal samples.

Nonetheless, these results are very consistent and suggest that the first Lapita occupation of the site occurred sometime around $3200 \mathrm{BP}$. This occupation (Zone 3) is in all excavated levels characterised by very fine dentate stamped decorations on pottery, a characteristic generally attributed to Far Western Lapita, as well as plain and incised pottery and obsidian flakes. A second Lapita occupation (Zone 2) occurred a short time afterwards, possibly around $3000 \mathrm{BP}$ and perhaps earlier. It is associated with large amounts of burnt turtle bone and ash as well as dentate-stamped pottery of a different style from Zone 3 . The dating of test pit F16 in 2005 suggests the same two occupations with possible evidence for a third, later occupation period, around 3000-2900 BP (Wk19706).

These results indicate that Makue was first settled around 3200 BP and that the Lapita occupation at this site had ended by around $2800 \mathrm{BP}$. These early dates are consistent with the associated cultural remains, obsidian and fine dentate pottery, and conform with the proposed chronology for the Santa Cruz Islands (Green 1991) reinforcing at the same time the evidence of a very rapid spread from the Bismarck Archipelago into Remote Oceania. Makué represents the earliest well dated evidence of human occupation of the Vanuatu islands discovered to date. A comparison of the pottery assemblage of the site with the one from Teouma on the island of Efate will probably help confirm the date of occupation of this later site. Obsidian is present throughout and there is no obvious difference in the distribution pattern observable at this stage between that found in Zone 3 and that in Zone 2.

\section{Obsidian analysis}

As mentioned previously, the Makué Lapita excavation uncovered a relatively large amount of obsidian - in comparison to most other Lapita sites in Remote Oceania including those in Vanuatu. Preliminary attempts to allocate the obsidian to a particular source were completed using density analysis.

Ambrose (1976) first demonstrated that the relative density of obsidian could be used to differentiate between the sources in the Pacific. This method has since been refined several times (Ambrose and Duerden 1982; Harris 1994; Torrence and Victor 1995). In this instance, artefacts were weighed in air, and then weighed again while immersed in PFMD (perfluoro-1-methyl-decalin) solution. A Mettler (AT261 DeltaRange) analytical balance with a density attachment was used for determining the weights. These weights and the temperature of the PFMD at the time of the analysis were incorporated into the following equation that applies Archimede's Theory of Water Displacement (Ambrose and Stevenson 2004 give an up-to-date explanation of this method to determine density):

$$
\begin{aligned}
& \qquad \mathrm{d}=\underline{\mathrm{m}}_{\underline{a}} \frac{((\mathrm{T}-965.99) /(-480.88))}{\left(\mathrm{m}_{\mathrm{a}}-\mathrm{m}_{1}\right)} \\
& \text { where } \mathrm{d}=\text { relative density, } \mathrm{m}_{\mathrm{a}}=\text { weight in air, } \mathrm{m}_{1}=\text { weight in PFMD, } \\
& \mathrm{T}=\text { temperature in degrees Celsius }
\end{aligned}
$$

Previous studies have shown that artefacts from New Britain have densities close to 2.35, while those from the Admiralty Islands have densities close to 2.38 (Ambrose 1976; Green and Anson 2000). The Banks Island sources, in Vanuatu, have a density around 2.44 (Ambrose 1976).

Density analysis is a fast and efficient analytical technique for the preliminary sourcing of an obsidian assemblage. Although the accuracy of measuring single artefacts can be adversely affected by a number of 
different variables, including high porosity or the presence of inclusions of different materials, the results at an assemblage level can be informative. This has been demonstrated by comparisons between obsidian artefacts analysed using both density and PIXE-PIGME (a chemical characterisation method) techniques (White and Harris 1997; Swete Kelly 2001).

\section{Results of Sourcing Study}

All the obsidian artefacts

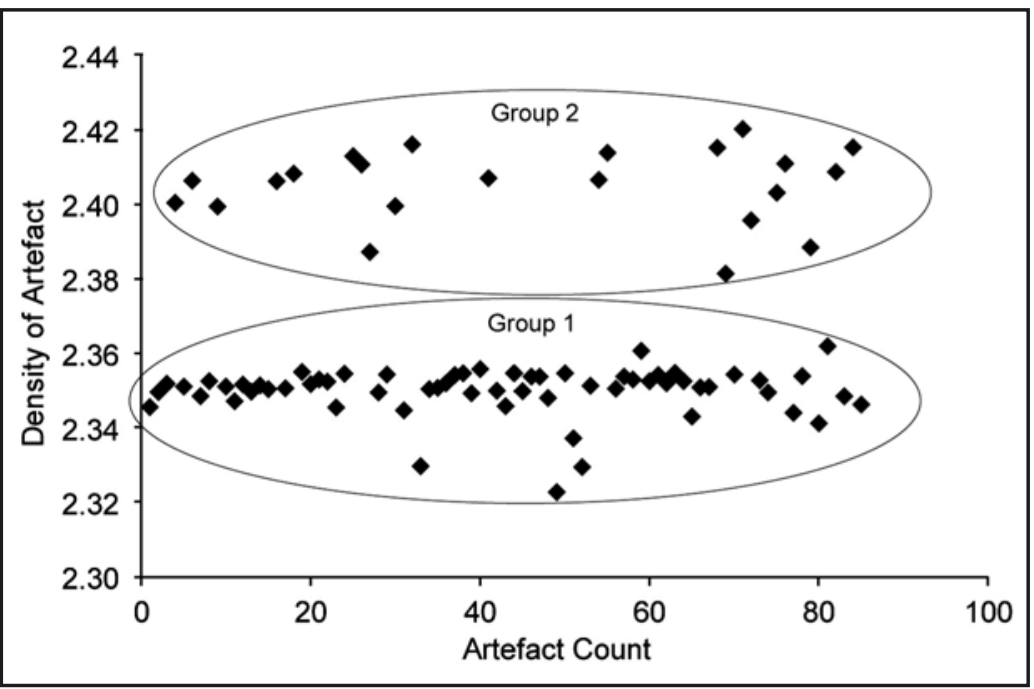
collected from the site of

Figure 6. Density of obsidian finds from the 2002 and 2003 field seasons at Makué.

Makué (in the 2002 and 2003 field seasons) have been included in this analysis. In the 2002 field season, 62 pieces of obsidian were excavated. A further 25 pieces of obsidian were excavated in the 2003 field season. One artefact was left out of the final results, as it gave a very low density reading which was attributed to its coarse, friable nature.

A large proportion of the obsidian found at Makué is coming from the island of New Britain in Papua New Guinea, most likely the Willaumez Peninsula sources (Group 1, Figure 6). As mentioned above Willaumez Peninsula sources have a density close to 2.35 . The source location of Group 2 is not as easy to determine. The Banks Island obsidian sources have a density of around 2.44, however none of the artefacts match this value. Nor do the obsidian artefacts in Group 2 clearly come from the source on Lou Island in the Admiralty group. While the range of obsidian densities from Lou Island vary between 2.38 and 2.404 this would still only encompass approximately half of the obsidian pieces tested (Group 2, Figure 6). These issues will be addressed by chemical analyses in the future, for now the clusters will be referred to as Group 1 and Group 2.

\section{Results of Comparative Measurements}

Basic measurements of maximum length, thickness and weight were made for the obsidian from the site of Makué. A broader technological analysis was also completed which will be included in a later article. The aim of these basic measurements was to provide a simple comparison to the sites excavated by Roger Green in the Reef and Santa Cruz Islands (Table 2). These assemblages were examined by Sheppard (1993) and the methods of analysis used herein are consistent with those used in his analyses. Although the sample sizes vary greatly, it can be seen that the average sizes and weights are quite similar. However, it is interesting to note that the Makué specimens lie at the lower end of the size and weight range of the Reef and Santa Cruz Islands. 
Table 2. Average measurements ( $\mathrm{mm}$ ) of obsidian from Makué, Aore Island compared to those of obsidian from the Reef and Santa Cruz Islands (from Sheppard 1993).

\begin{tabular}{lccc}
\hline & Max. Length & Thickness & Weight \\
\hline Aore Island, Makué & 17.45 & 4.00 & 1.17 \\
All artefacts $(n=84)$ & 16.59 & 3.65 & 0.89 \\
Group 1 $(n=61)$ & 20.23 & 5.06 & 1.83 \\
Group 2 ( $\mathrm{n}=20)$ & 19.6 & 5.63 & 2.39 \\
Reef/Santa Cruz Islands & 18.6 & 5.24 & 1.86 \\
SZ-8 ( $\mathrm{n}=329)$ & 13.7 & 3.78 & 1.06 \\
RF-2 (n=625) & & & \\
RF-6 $(\mathrm{n}=27)$ &
\end{tabular}

\section{Discussion}

An examination of the palaeo-coastlines on the island of Aore has revealed a new site of early human occupation in northern Vanuatu. This site, Makué contains a large amount of obsidian, when compared to other sites in the region of similar antiquity.

\section{Occupation and uplift}

Uplift has been a major cause of coastal change in Vanuatu which has important implications for the early archaeology of the islands (Pineda and Galipaud 1998; Bedford 2006; Bedford et al. 2006). The first settlements on Makué were probably located on a well protected, large, sandy shore, near a probable small freshwater stream on what used to be the north coast of Aore. It was also only a short sailing distance from the large Sarakata River on the Santo mainland. Over two centuries, the site was used several times as a seasonal camp rather than a long-term occupation. Evidence of abandonment is visible especially on the lower level (Zone 3) where some artefacts have been partly eroded before being covered by a sandy, sterile layer. The second occupation of the site probably occurred in the same sandy coastal environment. It is at this stage unclear whether the scattered shells and fragmented pottery found on the upper layer (Zone 1) attest to a further occupation of the site or are a disturbed component of the underlying level (Zone 2). It is also unclear yet how the undated Area A excavation relates to the well stratified Area B. On the basis of evidence provided by a comparison of the pottery and obsidian found in each of the areas, Area A could be of similar antiquity to Zone 3 in Area B. This will be investigated further in 2007.

The occupation of this site became unattractive as uplifting gradually affected the coastal environment. Dating this event is difficult and will require more research. The end of the Lapita occupation in Makué is possibly related to this event and therefore we cannot assume at this stage of the research that the latest date in Makué represents the latest occurrence of Lapita on Aore Island. No other human occupation is attested in this area prior to European arrival.

\section{Obsidian sources}

Makue is the first Lapita site with a large amount of obsidian south of the Santa Cruz Islands. A few pieces of obsidian (8 flakes, analysed by Ambrose and sourced to the Talasea and Lou area) had already been found in Malo (Hedrick 1971) but no site with large quantities of obsidian had been found so far south of the Santa Cruz area. There is, however, recent evidence from Teouma that this boundary may be extended south to Efate (Bedford et al. 2006). The preliminary density results suggest that most obsidian from Makué, as is the case in the Reef and Santa Cruz Islands, originated from Talasea, on the Willaumez 
Peninsula (New Britain) with some additional material from a yet unknown source, possibly Lou Island or the Banks Islands. Chemical analysis will be performed to verify the origin of these artefacts.

The density method of obsidian sourcing reveals large scale patterns in obsidian sourcing. However, obsidian from the Banks Islands overlaps in density with that from the Lou Islands sources and it is therefore difficult to establish with precision the respective proportion of each source with the density method. The problems associated with the density methods have been addressed by a number of researchers (Ambrose 1976; Ambrose and Stevenson 2004; Torrence and Victor 1995) and this aspect will be addressed with further analyses. Despite the limitations of the density method, upon initial observation the results presented herein appear to be similar to those obsidian sources identified for the sites on the Reefs-Santa Cruz Islands.

Obsidian from the Banks Islands is a low quality volcanic glass which has been widely used over the last millennium or so across a vast area, from Tikopia (Kirch and Yen 1982) in the west to Fiji in the east (Best 1984) and as far south as Santo (Galipaud 1998). The noted presence of a few flakes of Banks obsidian in some Malo Lapita sites could be interpreted as an admixture from more recent levels. However, in Makué, where the only occupation is Lapita, the presence of Banks obsidian, if it is confirmed, will indicate that Lapita sailors knew of the Banks and utilised its resources despite the fact that no Lapita sites have yet been located in the Banks group.

Obsidian finds in Makué were comparatively more abundant in the area excavated in 2002. It was first thought that this would demonstrate a chronological difference in the settlement, with an initial occupation further away from the sea (or at a time of higher sea level). So far dating of Area A has not been possible and future excavations will focus on obtaining an accurate chronology for this area.

\section{Comparisons with other sites}

The artefacts from Makue and those in the sites from the Reef and Santa Cruz Islands are similar in both size and weight. Sheppard (1993) examined the latter assemblages within a resource maximisation framework. He concluded that the use and discard of the obsidian was not consistent with a resource maximisation model. He concluded that social influences were affecting the use of the material and that the obsidian was 'socially maximised' upon acquisition but later utilised in an expedient manner. Specht's (2002) review of Lapita era obsidian finds was consistent Sheppard's conclusion, at least for the early Lapita sites. Since the evidence so far suggests that the Makué site is associated with the earliest Lapita occupation of Vanuatu and since the obsidian from Makué is similar in size to that from the Reef and Santa Cruz Islands, a similar commodity history may be present in northern Vanuatu. In future, a broader review of the Makué obsidian, taking into account a comprehensive technological analysis and comparisons with other Lapita assemblages, will address these issues further.

\section{Conclusions}

It is now clear that occupation at Makué was an important part of the original settlement of Vanuatu. The similarity of the assemblage of Makue with that from the Reef-Santa Cruz Islands, especially at Nenumbo suggest that the Reef-Santa Cruz area and northern Vanuatu have been an important stepping stone for the Lapita sailors on their voyage of discovery towards the south and east. The very early dates of the several layers of occupation at Makué support the hypothesis of an equally early settlement of Fiji and perhaps New Caledonia and are compatible with the tentative chronology for the Teouma site further to the south. The large amounts of flaked obsidian found at Makué are a good indicator of this antiquity but are probably also a distinctive trait of the function of this site, which needs to be further assessed following future excavations. 


\section{Acknowledgments}

The work in Malo and Aore was supported by a grant from IRD and later financial support from the French Embassy and the New Zealand High Commission in Port-Vila, as well as from the Department of Archaeology and Natural History, Australian National University. The Vanuatu Cultural Centre and Vanuatu Historic and Cultural Site Survey (VCHSS) staff helped at every stage to promote and implement the project. Many Vanuatu Cultural Centre fieldworkers and staff of the VCHSS took part in the research. Yoko Nojima and François Wadra played an important part during the initial phase of the project. The owner and manager of the Aore Resort and Aore Plantation supported us while in the field and gave us access to the archaeologically important areas. Our thanks extend to all who took part in the excavations, especially Stephan, and Rufino for their help in the field. Thanks also to Wal Ambrose who agreed to review this paper. We are particularly indebted to Chief Takau Mwele, traditional owner of the place and Chief Vira Joseph from Malo for the interest they have always shared and the kindness of their welcome.

\section{References}

Ambrose, W.R. 1976. Obsidian and its Prehistoric Distribution in Melanesia. In N. Barnard (ed.), Ancient Chinese Bronzes, Southeast Asian Metal and other Archaeological Artefacts, pp. 351-378. Melbourne: National Gallery of Victoria.

Ambrose, W.R. and P. Duerden 1982. PIXE Analysis in the Distribution and Chronology of Obsidian Use in the Admiralty Islands. In W.R. Ambrose and P. Duerden (eds), Archaeometry: an Australasian Perspective: 8390. Canberra: Department of Prehistory, RSPacS, Australian National University.

Ambrose, W.R. and C.M. Stevenson 2004. Obsidian density, connate water, and hydration dating. Mediterranean Archaeology and Archaeometry 4(2):17-31.

Bedford, S. 2003. The Timing and Nature of Lapita Colonisation in Vanuatu: The Haze Begins to Clear. In C. Sand (ed.), Pacific Archaeology: Assessment and Proposals. Proceedings of the International Conference for the 50th Anniversary of the First Lapita Excavation Koné-Noumea 2002, pp. 147-158. Nouméa: Les Cahiers de l'Archéologie en Nouvelle Calédonie 15.

Bedford, S. 2006. Pieces of the Vanuatu Puzzle: Archaeology of the North, South and Centre. Canberra: Pandanus Press, Australian National University. Terra Australis 23.

Bedford S., M. Spriggs and R. Regenvanu 2006. The Teouma Lapita Site and the early Human Settlement of the Pacific Islands. Antiquity 80:812-828.

Best, S. 1984. Lakeba: the prehistory of a Fijian Island. Unpublished PhD thesis, University of Auckland.

Bronk Ramsey, C. 2007. Deposition models for chronological records. Quaternary Science Reviews (INTIMATE special issue) in press.

Galipaud, J-C. 1998. Recherches archéologiques aux îles Torres. Journal de la Société des Océanistes 107:159-168.

Galipaud, J-C. 2000. The Lapita Site of Atanoasao, Malo, Vanuatu. World Archaeological Bulletin 12:41-55.

Garanger, J. 1972. Archéologie des Nouvelles Hébrides. Paris: Publication de la Société des Océanistes 30.

Green, R.C. 1976. Lapita Sites in the Santa Cruz Group. In R.C. Green and M.M. Cresswell (eds), Southeast Solomon Islands Culture History: A Preliminary Survey, pp. 245-65. Wellington: The Royal Society of New Zealand Bulletin 11.

Green, R.C. 1979. Lapita. In J.D. Jennings (ed.), The Prehistory of Polynesia, pp. 27-60. Cambridge, Mass.: Harvard University Press. 
Green, R.C. 1987. Obsidian results from the Lapita sites in the Reef/Santa Cruz Islands. In W.R. Ambrose and J.M.J Mummery (eds), Archaeometry: Further Australasian Studies, pp. 239-249. Canberra: Department of Prehistory, Australian National University.

Green, R.C. 1991. A reappraisal of the dating for some Lapita sites in the Reef/Santa Cruz group of the southeast Solomons. Journal of the Polynesian Society 100:197-207.

Green, R.C. and D. Anson 2000. Excavations at Kainapirina (SAC), Watom Island. New Zealand Journal of Archaeology 20 (1998):29-94.

Harris, M-N. 1994. Relative Density Source Characterisation of Obsidian from the Bismarck Archipelago. Honours thesis. University of Sydney.

Hébert, B. 1965. Nouvelles Hébrides. Contribution à l'Étude Archeologique de l'Île Éfaté et des Îles Avoisantes. Études Mélanésiennes 18-20:71-98.

Hedrick, J.D. 1971. Lapita Style Pottery from Malo Island. Journal of the Polynesian Society 80(1):5-19.

Kirch, P.V. and D.E. Yen 1982. Tikopia: The Prehistory and Ecology of a Polynesian Outlier. Honolulu: BP Museum Bulletin 238.

McCormac F.G., A.G. Hogg, P.G. Blackwell, C.E. Buck, T.F.G. Higham and P.J. Reimer 2004. SHCal04 Southern Hemisphere Calibration 0 - 1000 cal BP Radiocarbon 46:1087-1092.

Pineda, R. and J-C. Galipaud 1998. Evidences archéologiques d'une surrection différentielle de l'île de Malo (Archipel du Vanuatu) au cours de l'holocène récent. Comptes-Rendus de l'Académie des Sciences 327:777-779.

Sheppard, P.J. 1993. Lapita Lithics: Trade/Exchange and Technology. A View from the Reefs/Santa Cruz. Archaeology in Oceania 28:121-137.

Sheppard, P.J. and R.C. Green 1991. Spatial analysis of the Nenumbo (SE-RF-2) Lapita Site, Solomon Islands. Archaeology in Oceania 26:89-101.

Specht, J. 2002. Obsidian, Colonising and Exchange. In S. Bedford, C. Sand and D. Burley (eds), Fifty Years in the Field : Essays in honour and celebration of Richard Shutler Jr's Archaeological career, pp. 37-49. Auckland: New Zealand Archaeological Association Monograph 25.

Spriggs, M. and S. Wickler 1989. Archaeological Research on Erromango: Recent Data on Southern Melanesian Prehistory. Bulletin of the Indo-Pacific Prehistory Association 9:68-91.

Summerhayes, G. 2003. Modeling differences between Lapita obsidian and pottery distribution patterns in the Bismarck Archipelago, Papua New Guinea. In C. Sand (ed.), Pacific Archaeology: Assessments and Prospects, pp. 135-145. Nouméa: Les Cahiers de l'Archéologie en Nouvelle Calédonie 15.

Swete Kelly, M C. 2001. Lapita Lithics: an analysis of obsidian acquistion, utilisation and discard on the Anir Islands. Honours thesis, Australian National University.

Torrence, R. and K.L. Victor 1995. The Relativity of Density. Archaeology in Oceania 30:121-131.

White, J.P. and M-N. Harris 1997. Changing Sources: Early Lapita Obsidian in the Bismarck Archipelago. Archaeology in Oceania 32:97-107. 